\title{
ANALISIS HUBUNGAN BUDAYA ORGANISASI DENGAN KINERJA ORGANISISI: STUDI KASUS PERUSAHAAN KONTRAKTOR DI DAERAH ISTIMEWA YOGYAKARTA
}

\author{
Triapriono Kaidu \\ Magister Teknik Sipil, Program Pascasarjana, \\ Universitas Atma Jaya Yogyakarta \\ Jl. Babarsari No.44, Janti, Caturtunggal, Kec. Depok, \\ Kabupaten Sleman, Daerah Istimewa Yogyakarta 55281 \\ Email: Kaidutrapriono@gmail.com
}

\begin{abstract}
The tight competition in the construction business in the current global era demands that construction companies improve good organizations in competition. Organizational culture is one of the important factors that help in an organization, therefore the need for an organization to know and understand the organizational culture that is followed in its organization. This is related to the desired achievement of the organization in improving organizational performance. The aim of this research to identify organizational culture that is supported by contracting companies in the Special Region of Yogyakarta, to identify organizational performance and the hypothesis in this study relates to the alleged cultural relationship with organizational performance. Large and medium-sized contracting companies in Yogyakarta are especially predominantly Clan cultures compared to other cultures (Adocracy, Market, and Hierarchy) that are concerned with loyalty and tradition. The organizational performance of the eight companies is good. Organizational culture projects positive opposition to organizational performance and for each culture, the cultural hierarchy has a significant and positive assessment of other cultures (Clan, Adocracy, and Market). Organizational culture is an important asset for every contracting company to improve organizational performance.
\end{abstract}

Keywords: Clan, Adhocracy, Market, Hierarchy, Organizational Performance

\begin{abstract}
Abstrak
Ketatnya persaingan bisinis konstruksi di era global saat ini menuntut agar perusahaan konstruksi meningkatkan kinerja organisasi yang baik dalam menghadapi persaingan. Budaya organisasi menjadi salah satu faktor penting kaitannya dalam suatu organisasi, oleh karena itu perlunya suatu organisasi mengetahui dan memahami budaya organisasi yang dianuti dalam organisasinya. Hal ini berkaitan dengan tujuan pencapaian yang diingikan organisasi dalam meningkatkan kinerja organisasi. Penelitian ini bertujuan untuk mengidentifikasi budaya organisasi yang ditekanakan oleh perusahaan kontraktor di daerah Istimewa Yogyakarta, mengidentifikasi kinerja orgnisasi dan hipotesis dalam penelitian ini berkaitan dengan dugaan adanya hubungan budaya organisasi dengan kinerja organisasi. Perusahaan-perusahaan kontraktor besar dan menengah di daerah istimewa Yogyakarta cendrung dominan tipe budaya Clan dibandingkan dengan budaya lainnya (Adocracy, Market, dan Hierarchy) yang mementingkan kesetiaan dan tradisi. Kinerja organisasi dari kedelapan perusahaan tergolong baik. Budaya organisasi mempunya korelasi yang positif terhadap kinerja organisasi dan untuk masing-masing budaya, budaya Hierarchy mempunyai korelasi positis dan signifikan dari budaya lainnya (Clan, Adocracy, dan Market). Budaya organisasi menjadi aset yang penting bagi setiap perusahaan kontraktor untuk meningkatkan kinerja organisasi.
\end{abstract}

Kata Kunci: Clan, Adhocracy, Market, Hierarchy, Kinerja Organisasi

\section{PENDAHULUAN}

Pada era global saat ini salah satu masalah yang dihadapi setiap perusahaan jasa konstruksi adalah semakin ketatnya persaingan bisnis dalam industry jasa konstruksi. Dalam hal ini sumber daya manusia sangat memiliki peranan yang sangat penting dalam persaingan bisnis konstruksi saat ini. Perusahan yang memiliki sumber daya manusia yang baik dan organisasi yang baik akan dapat bersaing dengan perusahan lain.

Arditi et al, (2017) menjelaskan budaya organisasi sebagai pola asumsi dasar yang dibagikan dan dipelajari oleh kelompok untuk mengatasi masalah adaptasi ekstrenal dan integrasi internal yang telah bekerja dengan baik dan dianggap benar dan, oleh karena itu perlu diajarkan kepada anggota baru sebagai cara yang tepat untuk memahami, berpikir, dan terikat dengan masalahmasalah yang ada.
Schein, (2004) dalam Salem \& Alkhamali, (2014) berpendapat budaya organisasi adalah masalah serius yang menjadi perhatian bagi setiap organisasi untuk mencapai tujuan tampa habatan apapun. Dalam beroganisasi, orang-orang dari latar belakang budaya yang berbeda. Mereka berinteraksi satu sama lain membentuk pola prilaku, sikap, dan praktik yang ditunjukan organisasi. Keberhasilan atau peningkatan kinerja hampir selalu dikaiktan dengan budaya organisasi. Hal ini menujukan kinerja organisasi dalam perusahan modern perlunya mendapatkan perhatian dalam mengelolanya. Apabila kinerja dalam perusahaan tidak dikelola dengan baik maka akan dapat menjadi salah satu penghambat aktivitas perusahan dalam mencapai tujuan. Penataan kinerja ini tentunya memerlukan penyesuaian kondis atau keadaan perusahan agar sanggup bersaing dengan perusahan lainnya. Menurut Peloza \& Papania, (2008) banyak peneliti melakukan penelitian dengan asumsi bahwa 
budaya organisasi dapat membantu meningkatkan kinerja organisasi Oleh karena itu pentingnya setiap organisasi, baik pribadi maupun publik, untuk memahami budaya mereka sendiri sehingga manajemen dapat menggunakannya sebagai kontrol yang lebih besar terhadap kinerja organisasi

\section{LANDASAN TEORI \\ Budaya Organisasi}

Penelitian ini didasari oleh teori budaya organisasi menurut Cameron \& Quinn, (2006). Sebagai berikut:

\section{a. The Clan Culture (Budaya Clan)}

Budaya perusahan yang memiliki karakter kekeluargaan, dimana terdapat lingkungan yang mengatur perusahaan dengan baik melalui teamwork. Budaya ini juga berfokus pada pengembangan karateristik kerja sama tim dan loyalitas terhadap program yang dibuat. Pemberdayaan dan keterlibatan anggota tim dalam kegiatan yang berbeda dari organisasi yang diberikan tiap tahap dalam jenis budaya ini. Lingkungan kerja dalam budaya clan seperti kekeluargaan dimana pemimpin atau kepala organisasi dipandang mentor dan bahkan sebagai figur orang tua. Budaya clan menunjukan ciri khas pemimpi sebagai fasilitator, mentor, penyemangat, menekan pada pengembangan daya dan semangat kerja.

b. The Adhocracy Culture (Budaya Adhocracy)

Budaya adhocracy adalah budaya perusahaa yang menuntut inovasi dan inisiatif serta menciptakan produk baru dan jasa untuk mengantisipasi kebutuhan dimasa depan. Tugas utama dari manjemen adalah mendukung dan mendorong terciptanya semangat entreprenursihp dan kreativitas. Budaya adhocracy ini mengacu pada budaya dimana anggota didalam organisasi memilih untuk menujukan kemampuan mereka dan berani mengambik resiko untuk keberhasilan organisasi yang berkebelanjutan secara keseluruhan. Ciri khas yang paling menonjol dari budaya ini adalah inovasi tiap personal dan kemampuan untuk beradaptasi dengan perubahan baru dan menerima setiap tantagan dalam berorganisasi dimana berani mengambil resiko, antisipasi dan selalu inovasi.

c. The Market Culture (Budaya Market)

Budaya market adalah budaya perusahaan yang memiliki budaya asumsi pasar yang tidak ramah, kompetitif serta perilaku konsumen yang cendrung memilih dan tertarik pada nilai-nilai sehingga menempatkan organisasi pada bisnis yang selalu berusaha meningkatkan persaingan. Tugas utama manajemen adalah mengendalikan organisasi untuk mencapi produktivitas, hasil, tujuan dan serta keuntungan.

d. The Hierarchy Culture (Budaya Hierarchy)

Budaya hierarchy adalah budaya perusahaan yang ditandai dengan adanya bentuk perusahaan yang resmi dan terstruktur. Tugas utama manajemen adalah memproduksi barang dan jasa secara efisien sehingga kesejahteraan dalam perusahaan tercapai.
Berdasarkan masing-masing empat alternatif budaya organisasi, dilihat melalui enam dimensi budaya organisasi, yaitu sebagi berikut.

1. Karateristik Dominan

a. Organisasi adalah sebuah tempat yang sangat pribadi, hal ini seperti sebuah keluarga besar, dimana orang-orang bersama-sama membagi.

b. Organisasi adalah sebuah tempat berusaha yang sangat dinamis. Orang-orang rela untuk "menikam leher meraka" dan mengambil resiko,

c. Organisasi sangat berorentasi pada tujuan. Sebuah perhatian utama adalah dengan menyelesaikan pekerjaan. Orang-orang sangat kompetitif dan berorentasi pada perstasi.

d. Organisasi sebuah tempat yang terkontrol dan tersusun rapi. Prosedur formal sudah menjadi hal yang umum untuk dilakukan orang-orang.

2. Kepemimpinan Organisasi

a. Kepemimpinan dalam organisasi dipertimbangkan secara umum untuk menasehati, menfasilitasi, atau mengasuh.

b. Kepemimpinan dalam organisasi adalah kewirausahaan, menginovasi atau mengambil resiko.

c. Kepemimpinan dalam organisasi adalah agresif, fokus berorientasi pada hasil.

d. Kepemimpinan dalam organisasi adalah mengkordinasikan, mengorganisir atau berjalan mulus efisien.

3. Manajemen Karyawan

a. Gaya manajemen organisasi dikarakteristik dengan kerja tim, konsensus dan partisipasi.

b. Gaya manajemen dalam organisai dikarakteristik dengan pengambilan resiko secara individual, inovasi, kebebasan dan keunikan

c. Gaya manajemen dalam organisasi dikarakteristikan dengan kompetisi yang keras, tuntutan yang tinggi, dan partisipasi.

d. Gaya manajeman dalam organisasi dikarakteristikan dengan keamanan diri karyawan, kenyamanan, dapat diperdiksi, dan stabilitas dalam hubungan.

4. Perekat Organisasi

a. Perekan yang dapayt merekat organisasi adalah loyalitas dan kepercayaan diantara sesame anggota organisasi. Komitmen untuk organisasi ini berjalan dalam tingkat yang tinggi.

b. Perekat yang dapat merekat organisasi adalah komitmen untuk inovasi dan pengembangan. Dalam hal ini adalah sebuah tekanan untuk menjadi ujung tombak.

c. Perrakat yang dapat merekatkan organisasi adalah tekanan untuk berprestasi dan pencapaian tujuan. Agresivtas dan memenangkan sesuatu dan motif yang biasa ada.

d. Perekat yang dapat merekat organisasi adalah aturan formal dan kebijakan. Memperbaiki organisasi agar berjalan halus adalah hal yang penting. 
5. Penekanan Strategi

a. Organisai menekankan pada pengenbangan dari segi sumberdaya manusia. Kepercayaan yang tinggi, keterbukaan dan partisipasi berlangsung lama.

b. Organisasi menekankan pada perolehan sumber daya baru dan membuat tantangan baru. Mencoba hal baru dan membuat prospek untuk peluang yang sangat dinilai.

c. Organisasi menekankan pada kegiatan kompetitif dan prestasi mencapai target yang tinggi dan memenangkan pasar secara dominan.

d. Organisasi menekanakan pada suatau keadaan permanen dan stabil. Efisiensi, pengadilanm dan operasi-operasi yang halus adalah yang sangat penting untuk dilakukan.

6. Kriteria Sukses

a. Orgsnisasi mendefinisikan sukses berdasar pada pengembangan dari sumber daya manusia, kerja tim, komitmen karyawan, dan perhatian pada orang-orang.

b. Organisasi mendefinisikan sukses berdasr pada memiliki banyak produk yang unuk dan terbaru. Organisasi adalah product leader dan innovator.

c. Organisasi mendefinisikan sukses berdasar memenangkan persaingan pasar dan melebihi kompetisi. Kepemimpinan pasar yang kompititf adalah kunci.

d. Organisasi mendefinisikan sukses berdasar pada efisiensi. Pengirimanan yang dapat diandalkan, penjadwalan

\section{Kinerja Organisasi}

Dalam penelitian ini mengunakan studi pustaka menilai kinerja organisasi menurut Bassioni, (2004) menggabungkan kinerja area dalam prespektif Balanced Scorecard, model manajemen mutu, dan aspek yang relevan dalam literatur. Dari beberapa kombinasi tersebut terdapat beberapa kriteria kinerja organisasi sebagai berikut :

1. Leadership

2. Customer Focus

3. Stakeholder Focus

4. Information and Analysis

5. Strategic Management

6. Innovation, Learning and Knowledge Management

7. People Management

8. Partnership and Supplier

9. Resource Management

10. Processes

11. Project Results

12. Costumer Results

13. Society and Stakeholder Results

14. Business Results

\section{METODE PENELITIAN}

Penelitian tentang analisis hubungan buadaya organisasi dengan kinerja organisasi dilakukan dengan studi literatur yang dilanjutkan dengan pengumpulan data primer menggunakan kuesioner yang disebarkan langsung ke 8 perusahaan kontraktor di daerah Istimewa
Yogyakarta. Dari 8 perusahaan tersebut dengan jumlah 5 responden pada masing-masing perusahaan kontraktor besar dan menengah dengan respondenya adalah project manager dan site manager di daerah istimewa Yogyakarta. Kuesioner yang akan disebarkan terdiri dari tiga bagian yaitu : data diri responden, budaya organisasi, dan kinerja organisasi. Kuesioner budaya organisasi berdasarkkan acuan dari buku Diagnosing and Changing Organizational Culture Cameron \& Quinn, (2006) dan kuesioner untuk kinerja organisasi mengunakan studi pustaka menilai kinerja organisasi menurut Bassioni, (2004) menggabungkan kinerja area dalam prespektif Balanced Scorecard,. Pada penelitian ini menggunkan pearson correlation sebagai dukungan untuk hubungan budaya organisasi dengan kinerja organisasi.

\section{ANALISIS DAN PEMBAHASAN}

\section{Budaya organisasi perusahaan Kontraktor}

Analisis mean secara keseluruhan berdasarkan setiap perusahaan kontraktor dari semua data diberikan oleh 40 responden dari 8 perusahaan kontraktor yang berada di daerah Istimewa Yogakarta. Nilai mean terbesar akan menjadi acuan untuk menentukan budaya organisasi yang dominan atau ditekankan di perusahaan kontraktor di daerah Istimewa Yogyakarta. Hasil dari pengelolahan data tersebut dapat dilihat pada tabel 1 .

Tabel 1. Budaya Organisasi perusahaan Kontraktor di daerah Istimewa Yogyakarta

\begin{tabular}{lllll}
\hline & \multicolumn{4}{c}{ Nilai Mean } \\
\cline { 2 - 5 } Perusahaan & Clan & Adhocracy & Market & Hierarchy \\
\hline P1 & 4.30 & 3.80 & 4.00 & 4.06 \\
\hline P2 & 4.40 & 3.83 & 3.83 & 4.23 \\
\hline P3 & 4.33 & 3.83 & 4.06 & 4.16 \\
\hline P4 & 4.13 & 3.80 & 4.10 & 4.13 \\
\hline P5 & 4.40 & 3.76 & 4.06 & 4.30 \\
\hline P6 & 4.33 & 3.76 & 3.63 & 3.90 \\
\hline P7 & 4.30 & 3.83 & 3.90 & 4.10 \\
\hline P8 & 4.30 & 3.63 & 3.97 & 4.07 \\
\hline Rata-rata & 4.31 & 3.78 & 3.94 & 4.12 \\
\hline
\end{tabular}

Sumber : Hasil pengelolahan data (2019)

Perusahaan kontraktor di daerah istimewa Yogyakarta dari nilai rata-rata keseluruhan dari budaya organisasi clan dengan nilai mean 4.31, adhocracy degan nilai mean 3.78, market 3,94, dan hieracy 4.12 dan lebih dominan ke budaya organisasi clan. Hal ini menunjukan bahwa perusahaan kontraktor didaerah Istimewa Yogyakarta menginginkan atau menekankan terciptanya lingkungan tempat kerja yang bersahabat dimana-mana orang-orang saling berbagi diantara mereka, seperti sebuah keluarga besar. Dimana pemimpin bertindak sebagai mentor, dan memiliki figur sebagai orang tua, terikat dalam kesetian tradisi, serta komitmen yang tinggi. Organisasi menitip beratkan mafaat jangka panjang pengembangan sumber daya manusia dan sensitivitas terhadap konsumen dan penghargaan tetrhatap manusia. 
Organisasi ini meningkatakan teamwork, peran serta, dan konsumen.

Menurut Cameron \& Quinn, (2006) jika dapat mengetahui tipe budaya organisasi akan bermanfaat, karena kesuksesan organisasi tergantung seberapa besar budaya organisasi tersebut dapat menyesuai dengan kondisi lingkungan yang kompetitif. Dimana jika karyawan dapat beradaptasi dan menerima budaya organisasi pada perusahaan yang mereka bekerja maka karyawan tersebut dapat merasa lebih nyaman berada didalam organisasi dan menunjukan loyalitas serta berupaya memberikan kontribusi yang baik untuk organisasi sehingga dapat memudahkan organisasi untuk mempertahankan karyawan yang berkualitas.

\section{Kinerja Organisasi}

Hasil analisis kinerja organisasi menunjukan bahwa perusahaan-perusahaan kontraktor besar dan menengah di daerah istimewa Yogyakarta pada masingmasing kriteria kinerja organisasi (kepemimpinan, fokus pelanggan, fokus stakeholder, analisis dan informasi, manajemen strategi, manajemen inovasi, pembelajaran dan pengetahuan, manajemen karyawan, manajemen kemitraan, pengelolahan sumber daya, proses, hasil proyek, hasil pelanggan, hasil masyarakat dan stakeholder, dan hasil bisinis). Hasil analisis dapat dilihat paadaa tabel 2 .

Tabel 2. Kinerja Organisasi perusahaan Kontraktor

\begin{tabular}{ll}
\hline Kinerja Organisasi & Mean \\
\hline kepemimpinan & 4,19 \\
\hline Fokus Pelanggan & 4,23 \\
\hline Fokus Stakeholder & 4,07 \\
\hline Analisi Dan informasi & 4,18 \\
\hline Manajemen Strategi & 4,28 \\
\hline Majemen Inovasi, pembelajaran dan & \\
pengetahuan & 4,23 \\
\hline Manajemen Karyawan & 4,32 \\
\hline Manajemen Kemitraan & 4,22 \\
\hline Pengelolahan Sumber daya & 4,40 \\
\hline Proses & 4,28 \\
\hline Hasil Proyek & 4,23 \\
\hline Hasil Pelanggan & 4,19 \\
\hline Hasil Masyarakat dan Stakeholder & 4,33 \\
\hline Hasil Bisnis & 4,18 \\
\hline Sumber Hasil pengelolahan data (2019)
\end{tabular}

Sumber : Hasil pengelolahan data (2019)

Dari hasil analisi data masing-masing kriteria kinerja organisasi mean sebesar 4,07-4,40 menunjukan bahwa perusahaan-perusahaan kontraktor besar dan menengah didaerah istimewa Yogyakarta tergolong kriteria kinerja organisasi baik.

\section{Hubungan Budaya Organisasi dengan Kinerja Organisasi}

Hubungan budaya organisasi dengan kinerja organisasi digunakan metode pearson product moment correlation, dimana budaya organisasi sebagai variable independen. Uji korelasi dilakukan untuk mengetahui ada tidaknya hubungan antara dua variable serta seberapa kuat tingkat hubungan yang ada. Dari uji ksorelasi akan dicari besar koefisien korelasi (r) yang nilainya -1 dan +1 . Jika $r$ positif, maka dikatakan mempunyai korelasi positif, dimana jika satu variable meningkat, maka variable lainnya ikut meningkat. Sebaliknya dikatakan negatif (r) jika suatu dikatakan turun akan membuat nilai variable lain turun. Bila nilai signifikan $\leq(\alpha)=0.05$; dapat disimpulkan terdapat hubungan yang signifikan.

Hasil analisi korelasi variable budaya organisasi dengan kinerja organisasi pada perusahaan kontraktor didaerah istimewa Yogyakarta ditunjukan pada table 3.

Tabel 3. Korelasi Budaya Oraganisasi dengan Kinerja Organisas

\begin{tabular}{clcc}
\hline & \multicolumn{1}{c}{$\begin{array}{c}\text { Budaya } \\
\text { Organisasi }\end{array}$} & $\begin{array}{l}\text { Kinerja } \\
\text { Organisasi }\end{array}$ \\
\hline $\begin{array}{l}\text { Budaya } \\
\text { Organisasi }\end{array}$ & $\begin{array}{l}\text { PearsonCor } \\
\text { elation }\end{array}$ & 1 & $.659\left(^{* *}\right)$ \\
\hline & Sig. (2-tailed & \multicolumn{2}{c}{.000} \\
\hline & $\mathrm{N}$ & 40 & 40 \\
\hline $\begin{array}{c}\text { Kinerja } \\
\text { Organisasi }\end{array}$ & $\begin{array}{c}\text { PearsonCor } \\
\text { elation }\end{array}$ & $.659(* *)$ & 1 \\
\hline & Sig. (2-tailed & .000 & \\
\hline & $\mathrm{N}$ & 40 & 40 \\
\hline
\end{tabular}

** Correlation is significant at the 0.01 level (2-tailed). Sumber : Hasil pengelolahan data (2019

Dari tabel 3 diatas diketahui nilai korelasi yang tebentuk antara budaya organisasi dengan kinerja organisasi sebesar 0,659 atau $(65,9 \%)$ merupakan nialai $r$ dengan sig (2-tailed) probabilitas $=0,00$. Dapat disimpulkan bahwa ada hubungan positif atau hubungan sangat kuat antara budaya organisasi dengan kinerja organisasi. Budaya organisasi sebagai aset penting bagi perusahaan kontraktor dalam meningkatkan kinerja organisasi.

\section{Hubungan Masing-Masing Budaya Organisasi Dengan Kinerja Organisasi}

Hubungan masing-masing budaya organisasi dengan kinerja organisasi digunakan metode pearson product moment correlation. Budaya organisasi dapat menjadi aset dan beban bagi perusahaan kontraktor, tergantung terhadap kinerja organisasi korelasi positif atau negatif. Bila nilai singnifikan $\leq(\alpha)=0.05$; dapat disimpulkan terdapat hubungan yang signifikan. Hasil analisis korelasi antara masing-masing tipe budaya organisasi dengan kinerja organisasi dapat dilihat pada tabel 4.

Tabel 4. Korelasi Masing-Masing Tipe Budaya Organisasi Dengan Kinerja Organisasi

\begin{tabular}{l|c|c}
\hline \multirow{2}{*}{\begin{tabular}{l} 
Budaya Organisasi \\
\cline { 2 - 3 } Clan
\end{tabular}} & $\begin{array}{c}\text { Pearson } \\
\text { Correlation }\end{array}$ & Sig. (2-tailed) \\
\hline \multicolumn{1}{c|}{\begin{tabular}{l}
\multicolumn{1}{c}{ Karakteristik } \\
Dominan
\end{tabular}} &, 504 &, 010 \\
\hline
\end{tabular}




\begin{tabular}{l|c|c}
$\begin{array}{l}\text { Kepemimpinan } \\
\text { Organisasi }\end{array}$ &,- 060 &, 711 \\
\hline $\begin{array}{l}\text { Manajemen } \\
\text { Karyawan }\end{array}$ &, 326 &, $040^{*}$ \\
\hline Perekat Organisasi &, 259 &, 107 \\
\hline Penekanan Strategi &, 358 &, $023^{*}$ \\
\hline Kriteria Sukses &, 173 &, 286 \\
\hline \multicolumn{1}{c}{ Adhocracy } &, 514 &, 001 \\
\hline $\begin{array}{l}\text { Karakteristik } \\
\text { Dominan }\end{array}$ &, 343 &, $030^{*}$ \\
\hline $\begin{array}{l}\text { Kepemimpinan } \\
\text { Organisasi }\end{array}$ &,- 290 &, 069 \\
\hline $\begin{array}{l}\text { Manajemen } \\
\text { Karyawan }\end{array}$ &, 257 &, 110 \\
\hline Perekat Organisasi &, 163 &, 314 \\
\hline Penekanan Strategi &,- 136 &, 404 \\
\hline Kriteria Sukses &, 512 &, $001^{* *}$ \\
\hline \multicolumn{1}{c|}{ Market } &, 401 &, 010 \\
\hline $\begin{array}{l}\text { Karakteristik } \\
\text { Dominan }\end{array}$ &, 390 &, $013^{*}$ \\
\hline $\begin{array}{l}\text { Kepemimpinan } \\
\text { Organisasi }\end{array}$ &, 566 &, $000^{* *}$ \\
\hline $\begin{array}{l}\text { Manajemen } \\
\text { Karyawan }\end{array}$ &, 305 &, 056 \\
\hline Perekat Organisasi &,- 258 &, 108 \\
\hline Penekanan Strategi &, 004 &, 981 \\
\hline Kriteria Sukses &, 292 &, 067 \\
\hline \multicolumn{1}{c|}{ Hierarchy } &, 535 &, 000 \\
\hline $\begin{array}{l}\text { Karakteristik } \\
\text { Dominan }\end{array}$ &, 556 &, $000^{* *}$ \\
\hline $\begin{array}{l}\text { Kepemimpinan } \\
\text { Organisasi }\end{array}$ &,- 128 &, 432 \\
\hline $\begin{array}{l}\text { Manajemen } \\
\text { Karyawan }\end{array}$ &,- 031 &, 851 \\
\hline Perekat Organisasi &, 201 &, 213 \\
\hline Penekanan Strategi &, 421 &, $007^{*}$ \\
\hline Kriteria Sukses &, 581 &, $000^{* *}$ \\
\hline Coratar is & & \\
\hline
\end{tabular}

**. Correlation is significant at the 0.01 level (2-tailed).

*. Correlation is significant at the 0.05 level (2-tailed). $\mathrm{n}: 40$

Sumber : Hasil pengelolahan data (2019)

Korelasi budaya Hierarchy terhadap kinerja organisasi adalah singnifikan $\leq 5 \%$ dan paling tinggi nilai koefisien korelasi 0,535 dibandingkan budaya lainnya (clan, adhocracy, dan market), akan tetapi korelasi budaya Hierarchy terhadap kinerja organisasi mempunya korelasi signifikan $\leq 5 \%$. Sedangkan untuk korelasi antara enanm dimensi dari masing-masing budaya terhadap kinerja organisasi, menunjukanan untuk dimensi karakteristik dominan diwakili budaya clan korelasi signifikan $\leq 5 \%$ dan nilai koefisien paling tinggi 0,581 dibandingkan dimensi karakteristik dominan budaya lainnya (adhocracy, market, dan hierarchy), untuk dimensi kepemimpinan organisasi diwakili budaya market korelasi signifikan $\leq$ $5 \%$ nilai koefisien korelasi lebih tinggi 0,566 dibandingkan dimensi kepemimpinan organisasi budaya lainya (clan, adhocracy, dan hierarchy), untuk manajemen karyawan diwakili budaya clan korelasi signifikan $\leq 5 \%$ dan nilai koefisien paling tinggi 0,326 dibandingkan dimensi manajemen karyawan budaya lainnya (adhocracy, market, dan hierarchy), untuk dimensi perekat organisasi tidak mempunyai korelasi terhadap kinerja organisasi, untuk dimensi penekanan strategi diwakili budaya hierarchy korelasi signifikan $\leq 5 \%$ dan nilai koefisien paling tinggi 0,421 dibandingkan dimensi penekanan strategi budaya lainnya (clan, adhocracy, dan market), dan untuk dimensi kriteria sukses diwakili budaya hierarchy korelasi signifikan $\leq 5 \%$ dan nilai koefisien paling tinggi 0,581 dibandingkan dimensi kriteria sukses budaya lainnya (clan, adhocracy, dan market).

Untuk mendukung hasil penelitian ini peneliti membandingkan salah satu penelitian sebelumnya oleh Novana \& Ogunlana, (2006) studi kasusu perusahaan konstruksi di Thailand. Penulis mengidentifikasi bahwa Karakteristik dominan dari perusahaan kontraktor adalah budaya clan. Gaya kepemimpinan yang digunakan dalam perusahaan kontraktor adalah budaya market. Manajemen karyawan di perusahaan sangat berorientasi hierarchy yang ditandai dengan keamanan kerja. Perekat organisasi yang menyatukan perusahaan ditandai oleh Budaya clan yang. Penekanan strategis dalam perusahaan diwakili oleh budaya. Perusahaanmendefinisikan kesuksesan berdasarkan budaya hierarchy. Manajer dan Para insinyur sepakat bahwa budaya yang paling kuat adalah budaya hierarchy.

Berdasarkan hasil temuan dalam penelitian ini dan penelitian sebelumnya yang telah dilakukan dapat disimpulkan bahwa budaya hierarchy berpengaruh terhadapat kinerja organisasi. Hal ini menunjukan responden merasakan adanya aturan dan kebijakan dari perusahaan kontraktor tempat mereka bekerja merupakan faktor yang dapat meningkatkan kinerja organisasi dalam linkungan kerja. Budaya organisasi dengan korelasi tinggi bukan berarti bahwa organisasi tersebut adalah yang terbaik dan paling tepat dibandingkan budaya organisasi lainnya, tetapi dapat dipertimbangkan sebagai budaya organisasi yang dapat diterapkan sepanjang waktu dalam perusahaan kontraktor bila perusahaan ingin meningkatkan kinerja organisasi

\section{PENUTUP \\ KESIMPULAN}

Berdasarkan dari beberapa hasil analisi yang telah dilakukan dan dibahas dapat ditarik kesimpulan antara lain:

1. Perusahaan-perusahaan kontraktor besar dan menengah di daerah Istimewa Yogyakarta lebih menginginkan atau menekankan tipe budaya Clan dibandingkan dengan tipe budaya lainnya (adhocracy, market, dan Hierarchy), yang artinnya perusahaan kontraktor di daerah istimewa Yogyakarta mementingkan kesetiaan dan tradisi.

2. Kinerja organisasi setiap perusahaan kontraktor di daerah istimewa Yogyakarta tergolong baik.

3. Budaya organisasi mempunyai hubungan yang positif dan singnifikan terhadap kinerja organisasi yaitu sebesar $65,9 \%$ 
4. Budaya Hierarchy mempunya hubungan paling kuat atau signifikan dibanding tipe budaya lainya (clan, adhocracy dan market) terhadap kinerja organisasi.

\section{SARAN}

Berdasarkan hasil penelitian yang didapat, penulis dapat memberikan beerapan saran:

1. Untuk karyawan perusahaan kontraktor harus dapat beradaptasi dan menerima budaya organisasi pada perusahaan yang mereka bekerja maka karyawan tersebut dapat merasa lebih nyaman berada didalam organisasi dan menunjukan loyalitas serta berupaya memberikan kontribusi yang baik untuk organisasi sehingga dapat memudahkan organisasi untuk mempertahankan karyawan yang berkualitas.

2. Untuk penelitian selanjutnya, sebaiknya peneliti selanjutnya tidak hanya meneliti budaya organisasi yang tumbuh atau ditekankan oleh perusahaan kontraktor, tetapi juga meneliti budaya seperti apa yang diinginkan karyawan perusahaan kontraktor.

\section{DAFTAR PUSTAKA}

Arditi, D., Nayak, S., \& Damci, A. (2017). Effect of organizational culture on delay in construction. International Journal of Project Management, 35(2), 136-147. https://doi.org/10.1016/j.ijproman.2016.10.018

Bassioni, H. A. (2004). Framework For Measuring Business Performance in Construction Contracting Organisations. Doctor of Philosophy of Loughborough UniversityA Doctoral Thesis Submitted .

Cameron, K. s., \& Quinn, R. E. (2006). Diagnosing and Changing Organizational Culture. The Jossey-Bass Business \& Management Series.

Novana, M., \& Ogunlana, S. O. (2006). Organizational Culture Profile Of Construction Companies In Thailand. International Conference on Construction, Culture, Innovation and Management (CCIM), Dubai, UAE., 279-288. Retrieved from

Peloza, J., \& Papania, L. (2008). The Missing Link between Corporate Social Responsibility and Financial Performance: Stakeholder Salience and Identification. Corporate Reputation Review, 11(2), 169-181. https://doi.org/10.1057/crr.2008.13

Salem, K., \& Alkhamali, H. (2014). Leadership Style, Organisational Culture and Disputes in Public Construction, Heriot-Watt University,1-383. 